\title{
Tightening the noose of central government control over policing in Ireland: innovations in the Garda Síochána Act 2005
}

\author{
DERMOT P J WALSH *
}

University of Limerick

\begin{abstract}
Introduction
$\mathrm{T}$ There is a long tradition of central government control over policing in Ireland. ${ }^{1}$ This was continued and, if anything, strengthened after independence despite the replacement of the Royal Irish Constabulary with the Garda Síochána. The established concept of a national police force was retained, ${ }^{2}$ as was its subordination to central government. ${ }^{3}$ Although the legislation actually appeared to leave the Garda Commissioner with unfettered discretion over the direction and control of the force, ${ }^{4}$ the intention was always that he would function as the servant of the government. When introducing the legislative proposals in the Dáil, for example, the Minister for Justice (Kevin O'Higgins) linked the national status of the force with the necessity for direct government control as follows:
\end{abstract}

As the force is not local, but is an organised National Police Force, it is essential that it should not exist out of the immediate authority of the Executive Council.

* Professor of Law, School of Law, University of Limerick. The research for this paper was made possible by the grant of a Government of Ireland Senior Research Fellowship in the Humanities and Social Sciences by the Irish Research Council for the Humanities and Social Sciences.

1 See S H Palmer, Police and Protest in England and Ireland 1780-1850 (Cambridge: Cambridge University Press 1988), pp. 92-190, 198-269, 323-75, 403-8, 472-509; T Bowden, Beyond the Limits of the Law (Harmondsworth: Penguin 1978), pp. 169-73; T Salmon, "The civil power and aiding the civil power: the case of Ireland" in J Roach and J Thomaneck (eds), Police and Public Order in Europe (London: Croom Helm 1985); R Hawkins, "Dublin Castle and the RIC 1916-1922" in D Williams (ed), The Irish Struggle 1916-1926 (London: Routledge Kegan Paul 1966); K Boyle, "Police in Ireland before the Union” (1973) 8 Irish Jurist 323.

2 The Garda Síochána was formed in 1922 to replace the Royal Irish Constabulary throughout the state, with the exception of the Dublin metropolitan area where the Dublin Metropolitan Police (DMP) was retained temporarily. The DMP and the Garda Síochána were merged as the Garda Síochána by the Police Forces Amalgamation Act 1925. For a history of the DMP, see J O'Herlihy, The Dublin Metropolitan Police: A short history and genealogical guide (Dublin: Liffey Press 2001).

3 For an account of the establishment of the Garda Síochána, see C Brady, The Guardians of the Peace (Dublin: Gill \& Macmillan 1974); L McNiffe, A History of the Garda Siochana (Dublin: Wolfhound Press 1997); G Allen, Policing Independent Ireland 1922-1982 (Dublin: Gill \& Macmillan 1999).

4 See D P J Walsh, The Irish Police: A legal and constitutional perspective (Dublin: Round Hall Sweet \& Maxwell 1998), p. 107. 
A provision that all officers should be appointed by the Executive Council will give a proper constitutional derivation to their authority, and a proper direction to their allegiance. ${ }^{5}$

For at least the first five decades, this position was sustained primarily through the government's budgetary control and power of hire and fire over officers from commissioner all the way down to and including the middle management rank of superintendent. ${ }^{6}$ In the period from August 1922 up to the end of the 1970s, two commissioners were sacked following a change of government, while another two were appointed directly from positions as senior officials in the Department of Justice. By the end of the 1960s it was generally acknowledged that the degree of central government/political control over the Garda Síochána was a problem that needed to be addressed. ${ }^{7}$

During the 1970s, the English concept of constabulary independence ${ }^{8}$ began to take hold in Ireland as central government increasingly promoted the image of the police as a semi-autonomous public service, at least in matters not affecting the security of the state. This was reflected in the persistent refusal of the minister to accept responsibility in Parliament for questions on or criticisms of operational policing policies, practices and incidents. ${ }^{9}$ Unfortunately, this was not accompanied by a refusal to impose party political preferences and demands on the force when the need arose. ${ }^{10}$ The net effect was that government was able to use the national police force as its servant, while retaining the option of being able to throw up the screen of police operational independence when it wanted to avoid responsibility for unpopular, incompetent or unlawful police policies, practices or actions. This was made possible by the lack of specificity on the governance of the Garda Síochána in its founding legislation.

Surprisingly, the legislative framework which was fashioned in difficult circumstances in the newly independent Irish State of the 1920s survived right through to the early years of the 21 st century. Ultimately, growing public alarm over policing methods provided the impetus for a major legislative revision in the form of the Garda Síochána Act 2005.11 Comment on this Act has tended to focus, understandably, on the new independent complaints procedure that it establishes. ${ }^{12}$ The Act, however, also had a much broader and more ambitious objective of effecting the first complete overhaul of police governance in Ireland since the 1920s. When introducing it as a Bill in the Dáil, the Minister for Justice, Equality and Law Reform said that:

5 Dáil Debates, vol. 4, c. 1688 (1923).

6 See Walsh, The Irish Police, n. 4 above, chs 2 and 5.

7 See Commission on the Garda Síochána, Report on Conditions of Service (Dublin: Stationery Office 1970); Brady, Guardians of the Peace, n. 3 above, ch. 14.

8 See Royal Commission on the Police, Final Report Cmnd 1728 (London: HMSO 1962); R v Commissioner of the Police of the Metropolis, exparte Blackburn (No. 1) [1968] 2 QB 118; L Lustgarten, The Governance of Police (London: Sweet \& Maxwell 1986); G Marshall, Police and Government (London: Methuen 1965); N Walker, Policing in a Changing Constitutional Order (London: Sweet \& Maxell 2000) .

9 See Walsh, The Irish Police, n. 4 above, at ch. 12. Note also the criticism in the first Morris Report that the department was "now utterly isolated from Garda Headquarters" in the sense that it rarely raised queries abut Garda operations; Report on Explosives "Finds" in Donegal (Dublin: Stationery Office 2004), at para. 13.07.

10 Walsh, n. 4 above, The Irish Police, at ch. 5. See also the example of accessing confidential Garda files at p. 176 below.

11 For a summary of police practices and actions that gave cause for concern, see D P J Walsh, Human Rights and Policing in Ireland: Law, policy and practice (Dublin: Clarus Press 2009), Part 2.

12 For a notable exception, see B Vaughan, "A new system of police accountability: the Garda Síochána Act 2005” (2005) 15(2) Irish Criminal Law Journal 18. 
it contains the most important legislative proposals on policing ever to come before the Houses of the Oireachtas ... It will act as a modern constitution for a modern and even more professional police force at the beginning of a new century. ${ }^{13}$

This "constitution" redefines the relationship between the force and the minister, the government and the Oireachtas in a manner which, it is submitted, formalises and strengthens central government control over policing in Ireland to an unprecedented degree.

Many of the changes introduced by the Act seem to have been imported from England, Wales and Northern Ireland, where they have been a feature of police governance and accountability for well over a decade in the context of regional police forces and a tripartite structure of governance. ${ }^{14}$ In Ireland they will operate in the very different environment of an established national police force that has always been subject to the dual control of the Garda Commissioner and the Minister for Justice, Equality and Law Reform. ${ }^{15}$ The changes in question include: ministerial directives, priorities and performance targets; annual policing plans and multi-annual strategy statements; new accountability arrangements; and a Garda Inspectorate. ${ }^{16}$ In this article, each will be outlined in turn, followed by a brief acknowledgment of some counterbalancing forces in the form of local policing committees and the Garda Síochána Ombudsman Commission. With particular reference to Garda strategy statements and policing plans, it will be suggested that the new architecture enhances central political and institutional control over policing, without necessarily delivering commensurate dividends in transparency, accountability and community engagement.

\section{Retention and strengthening of existing controls}

The 2005 Act retains the commissioner's statutory power of direction and control over the force, ${ }^{17}$ but qualifies it in a manner which expresses the commissioner's subordination to the minister and the government to an extent that was not apparent in the previous legislation. ${ }^{18} \mathrm{~A}$ similar approach is taken to the other established mechanisms of government control. The power to remove the commissioner, for example, is expressed in terms which leave no doubt that the commissioner is expected to follow government orders. The statutory grounds upon which he or she can be removed expressly include a failure to have regard to any relevant policies of the minister or the government or any

13 Dáil Debates, vol. 597, c. 953.

14 There is now an extensive literature on the police governance and accountability reforms that have been introduced in England and Wales and Northern Ireland from the 1990s. See e.g. N Walker, Policing in a Changing Constitutional Order (London: Sweet \& Maxwell 2000); I Loader and A Mulcahy, Policing and the Condition of England: Memory, politics and culture (Oxford: Oxford University Press 2003); S Savage, Police Reform: Forces for change (Oxford: Oxford University Press 2007); R Reiner and S Spencer, Accountable Policing (eds) (London: IPPR 1993); E McLaughlin, The New Policing (London: Sage 2007), ch. 7; R Reiner, The Politics of the Police 3rd edn (Oxford: Oxford University Press 2000), ch. 6; T Jones, "The accountability of policing" in T Newburn (ed.), Handbook of Policing 2nd edn (Cullompton: Willan 2008), ch. 26; B Loveday, "New directions in accountability" in F Leishman et al. (eds), Core Issues in Policing (Harlow: Longman 2000), pp. 213-31; I Loader, "Plural policing and democratic governance" (2000) 9 Social and Legal Studies 323-45; A Mulcahy, Policing Northern Ireland: Conflict, legitimacy and reform (Cullompton: Willan 2006).

15 Central government control over policing in Ireland has never been shared with a police authority or policing board/commission.

16 In so far as there is a domestic blueprint for these "innovations", it is to be found in the proposals of the Report of the Steering Group on the Efficiency and Effectiveness of the Garda Siochana (Dublin: Government Stationery Office 1997).

17 Garda Síochána Act 2005, s. 26(1).

18 E.g. the Act states that in the performance of his or her functions the commissioner must have regard to, inter alia, any relevant policies of the minister or the government: ibid. s. 26(2)(c). 
written directive issued to the commissioner by the minister (see the next section below). ${ }^{19}$ In addition, the commissioner, and any officer right down to superintendent rank, can be removed by the government where it is of the opinion that that would be in the best interests of the force. ${ }^{20}$ While a literal interpretation of the previous legislation suggests that the power of removal was absolute, a more limited interpretation was offered by some of the Supreme Court judges in Garvey v Ireland, ${ }^{21}$ where Commissioner Garvey successfully challenged his removal on the grounds of natural justice. ${ }^{22}$

The one established control mechanism that has been dispensed with is the designation of the Secretary General of the Department of Justice, Equality and Law Reform as the Accounting Officer for the force. ${ }^{23}$ The Act confers this status on the Garda Commissioner, ${ }^{24}$ thereby affording him or her greater freedom and flexibility in the management of the Garda budget and, by extension, in the planning and management of policing policies, operations and decision-making. The commissioner is no longer obliged to clear decisions having budgetary implications with the department. That, of course, may simply be an exercise in bringing the law into line with practice, as the commissioner has been generally free of departmental interference in operational matters over the past few decades. Nevertheless, it does have some implications for the status of the commissioner and the independence of the Garda. Designating the chief officer as the Accounting Officer brings the Garda Síochána into line with semi-state bodies and suggests that the force can no longer be understood simply as an appendage of the department. It does not follow, however, that this is part of a wider agenda to remove the Garda from the direct control of the minister and the government. Other provisions of the Act suggest that it is little more than an administrative division of labour which is not meant to detract in any way from central government control over policing.

\section{The directive power}

The 2005 Act introduces several innovative mechanisms through which the minister can impact directly on Garda policies, priorities and operational decision-making. The one which represents the most clearcut break with the established theory of Garda independence from ministerial control is undoubtedly that which empowers the minster to issue directives to the Garda Commissioner. The Act stipulates that, following the approval of the government, the minister may issue written directives to the commissioner concerning any matter relating to the Garda Síochána. ${ }^{25}$ The commissioner is statutorily obliged to comply with any such directive ${ }^{26}$ and must inform the minister of the measures that have been taken to comply with a directive within the time specified by the minister. ${ }^{27}$ As will be seen, there is some uncertainty over the full scope of this power. That, however, does not detract from its overall significance in redefining or clarifying (depending on one's interpretation of the pre-existing position) the division of power in policing matters between the Garda Commissioner and the government of the day. Now, the latter enjoys

19 Garda Síochána Act 2005, s. 11(1)(a).

20 Ibid. ss. 11(1)(c) and 13(2).

21 [1981] IR 77.

22 For discussion, see Walsh, The Irish Police, n. 4 above, pp. 122-4.

23 On the general subject of the accounting officer and the broader implications of designating the secretary general or the commissioner as accounting officer, see ibid. pp. 134-9.

24 Garda Síochána Act 2005, s. 43.

25 Ibid. s. 25(1).

26 Ibid. s. 25(2).

27 Ibid. s. 25(5). 
an unequivocal power to determine and direct Garda policies, priorities, strategies and even operational decisions. The explicit inclusion of such a power in the Act is of immense significance. In effect it is an official declaration that the Garda and its members are the servants of the government, as distinct from the state or the people. ${ }^{28}$

It is important to acknowledge that there are limits to the minister's directive power. The Act states specifically that it cannot be used to limit the independence of a member of the Garda Síochána in performing functions relating to the investigation of a specific offence or the prosecution of an offence. ${ }^{29}$ The extent to which this protects Garda independence from ministerial control is not entirely clear. It is likely, however, that it is nothing more than an affirmation of the fact that police powers are conferred directly on each individual member of the Garda and can only be exercised at the discretion of each member, and not at the direction of a more senior officer or external authority such as the minister. ${ }^{30}$ Accordingly, the directive power does not authorise the minister to order the arrest (or release from Garda custody) of an individual or the search of specified premises or the prosecution of an individual. There can be no doubt, however, that the directive power can be used to require the commissioner to implement a particular policy, priority or strategy. Equally, there is no reason why it cannot be used to compel the commissioner to pursue a particular operation, even if that operation entailed the investigation of the alleged criminal or the political activities of an individual or organisation. This will be permissible so long as it stops short of usurping a member's discretion over whether to exercise a coercive power against a specific individual or property. It follows that it would be lawful, for example, for the minister to give the commissioner a directive to use all available resources to prevent protestors from restricting access to a designated area such as an industrial site, business premises or public offices.

In the Dáil debates on the Bill the minister attempted to quell fears that the introduction of the directive power would usher in partisan political control of the force. He explained that the power was necessary to enable the government to respond decisively and effectively to protect the interests of the state. ${ }^{31}$ As an example of its potential use he described a scenario in which it would be necessary for the government to issue a directive to the Garda Commissioner to close the border in response to an outbreak of foot and mouth disease in Northern Ireland. According to the minister, such a decision could not be left to the discretion of the commissioner. The reality, of course, is that the commissioner would respond immediately to any such request conveyed by the government irrespective of whether it was in the form of a directive. More likely examples might arise from the government's desire to respond to: threats of major disruption posed by protestors at a high profile meeting of EU leaders in Dublin; the prospects of severe social and economic dislocation resulting from strikes in essential services; or a media-generated panic over the challenge presented to the administration of criminal justice by feuding criminal gangs.

The legislation itself acknowledges that the power might be used in a manner which impacts on state security or the investigation of an offence. It stipulates that where the minister issues a directive, a copy must be laid before each House of the Oireachtas unless

28 Paradoxically, the contents of the declaration specified in s. 16(1) of the 2005 Act to be made by each member on appointment to office makes no mention of serving the government, while its predecessor expressly committed him or her to "render good and true service and obedience to Ireland and its constitution and government as by law established" (emphasis added); see Police Forces Amalgamation Act 1925, s. 11 and Sch. 4.

29 Garda Síochána Act 2005, s. 25(4).

30 See Walsh, The Irish Police, n. 4 above, pp. 65-72.

31 Dáil Debates, vol. 597, cc. 955-6. 
compliance with that requirement might prejudice the security of the state or impede the prevention, investigation or prosecution of an offence - in which case it will be sufficient to lay a written statement to the effect that a directive has been issued. ${ }^{32}$ This confirms that the power can be used to direct Garda policy and/or practice in a particular operation. More disturbing is the fact that it is in such highly sensitive aspects of policing that the minister can avoid the transparency and accountability checks and balances otherwise associated with the power. Not only is it a key instrument in securing political control over policing operations, it also has the potential to harness police power in the service of a governing party's interests over those of their opponents or local communities.

The availability of this directive power reflects a more concentrated degree of central government control over policing, relative to that applicable in some other jurisdictions such as England and Wales, Northern Ireland and New Zealand. In Northern Ireland, the Secretary of State has no power to issue directives on operational policing matters. The most he or she can do in this respect is to set long-term policing objectives, issue codes of practice to the Chief Constable on the discharge of his or her functions and promulgate regulations on the use of specified facilities, equipment or services by the force. ${ }^{33}$ The Home Secretary's powers over police forces in England and Wales are more substantial. The Home Secretary can respond to an adverse inspection report on a force by giving directions to a local/regional police authority to take remedial measures, which may include the adoption of an action plan with a view to promoting the efficiency and effectiveness of its force. ${ }^{34}$ While this power, together with a range of other powers and devices, ${ }^{35}$ is being used very effectively by the Home Secretary to impose Home Office priorities, policies and standards on police forces generally, ${ }^{36}$ it still falls short of the Irish power to issue directives on operational policing matters.

New Zealand offers a very apt comparator to Ireland not just because it is policed by a single national force similar in size to the Garda Síochána, but also because it has recently undertaken a fundamental overhaul of its policing legislation along the lines of the Garda Síochána Act 2005. It stipulates that the Police Commissioner is responsible to the minister for a range of matters, including giving effect to any lawful ministerial directions. ${ }^{37}$ Critically, however, it goes on to state that the commissioner is not responsible to, and must act independently of, any Minister of the Crown regarding: the maintenance of order in relation to any individual or group of individuals; the enforcement of the law in relation to any individual or group of individuals; the investigation and prosecution of offences; and decisions about individual police employees. ${ }^{38}$ The Act also stipulates that no police employee may, when exercising any power or carrying out any function or duty, act under the direction, command or control of a Minister of the Crown. ${ }^{39}$ This reflects a very clear

32 Garda Síochána Act 2005, s. 25(3).

33 Police (Northern Ireland) Act 1998, s. 40 and Police (Northern Ireland) Act 2000, ss. 24-7.

34 Police Act 1996, ss. 40, 41A and 41B.

35 See e.g. the provisions on the adoption of a national policing plan, the issuing of codes of practice on the discharge of the functions of chief constables with a view to promoting the efficiency and effectiveness of the force or forces concerned, and the promulgation of regulations requiring all police forces to adopt particular procedures or practices and regulations on equipment to be used by police forces: Police Act 1996, ss. 36A, 39A, 53 and $53 \mathrm{~A}$.

36 See, T Jones, "The accountability of policing" in Handbook of Policing, n. 14 above, ch. 26; N Walker, Policing in a Changing Constitutional Order (London: Sweet \& Maxwell 2000), ch. 7; Savage, Police Reform, n.14 above.

37 Policing Act 2008, s. 16(1).

38 Ibid. s. 16(2).

39 Ibid. s. 30(4). 
intent to prevent police law enforcement or public order maintenance operations from falling under ministerial direction or influence. Ireland, by comparison, conveys a distinct preference for enhancing direct ministerial control in these matters.

In practice, of course, it is unlikely that the Irish minister would have to resort formally to the directive power on a regular basis to satisfy his or her policing requirements. The mere existence of the power should be sufficient in itself to deliver a compliant commissioner. As in England and Wales and in Northern Ireland, there are other provisions in the Act which will enable the minister to shape Garda policies, priorities and strategies to his or her liking in a less public and confrontational manner. The minister can determine and revise priorities for the Garda and establish and revise performance targets from time to time. ${ }^{40}$ The minister must consult with the Garda Commissioner in these matters, ${ }^{41}$ and supply the commissioner with a copy of the determined priorities, established targets and any revisions thereto. ${ }^{42}$ As soon as practicable after their adoption, a copy of these priorities and targets must be laid before each House of the Oireachtas. ${ }^{43}$ The commissioner must have regard to these priorities and targets in performing his or her functions and must inform the minister of the measures taken to achieve them. ${ }^{44}$ When combined with the directive power, these provisions reflect an architecture with a heavy emphasis on strong central government control over policing.

\section{Strategy statements and policing plans}

Strategy statements and policing plans provide another vehicle for ministerial control. The Act requires the commissioner to formulate a strategy statement every three years and an annual policing plan. ${ }^{45}$ Both are subject to ministerial control. The strategy statement must be in such form and manner as the minister may direct, and its contents must reflect relevant government policy and ministerial priorities. ${ }^{46}$ It must also include an identification of issues of concern to Departments of State and other state agencies, together with a plan for managing those issues. ${ }^{47} \mathrm{~A}$ similar subordination to ministerial and government requirements applies to the preparation and contents of the annual policing plans. ${ }^{48}$ The commissioner must submit the statement/plan in draft form to the minister for approval. ${ }^{49}$ The latter must approve them as submitted, or with such amendments as may be determined after consulting the commissioner. ${ }^{50}$ Once approved, copies are laid before each House of the Oireachtas. ${ }^{51}$ Ultimately, the commissioner must have regard to them when performing his or her functions. ${ }^{52}$ One concession to a community input to policing plans that is not present in the strategy statement is the facility (expressed in

\footnotetext{
40 Garda Síochána Act 2005, s. 20(1).

41 Ibid. s. 20(2)(a).

42 Ibid. s. 20(2)(b). The wording actually refers to determined priorities and established priorities. Presumably the latter should read "established targets".

43 Ibid. s. 20(3).

44 Ibid. ss. 26(2) and 20(4).

45 Ibid. ss. 21(1) and 22(1).

46 Ibid. s. 21(2) and (3).

47 Ibid. s. 21(2)(c).

48 Ibid. s. 22(2).

49 Ibid. ss. 21(1) and 22(4).

50 Ibid. ss. 21(4) and 22(5).

51 Ibid. s. 21(5) and 22(6).

52 Ibid. s. 26(2).
} 
optional terms) to have regard to the most recent report from each joint policing committee (see the final section below). ${ }^{53}$

Annual policing plans have been a statutory requirement in police governance in England and Wales from the 1990s. ${ }^{54}$ For the most part, they were part of a broader drive to deliver greater managerial efficiency, performance accountability and value for money in policing and in the public services generally. ${ }^{55}$ In the case of the police, they have combined with codes of practice, action plans, performance targets, directions and budgetary decisions emanating from the Home Secretary in a manner which has enhanced central government control at the expense of the local/regional Police Authorities. ${ }^{56}$ Similar provisions were introduced to Northern Ireland from 1998. ${ }^{57}$

In Ireland, the strategy statements have been introduced in the context of a national police organisation that was already characterised by an acute degree of political and institutional centralisation and a lack of transparency. In one sense, therefore, they reflect only a minor realignment in the police power relationship between central government and Garda management. ${ }^{58}$ On the other hand, they do have the potential to inject a greater degree of democratic participation in, and accountability for, policing priorities, strategies and performance. They still are the only regular source of public information on these matters. In their absence, the Garda Commissioner would enjoy the freedom to formulate his or her own preferences hidden from public view and subject only to the possibility of ministerial directives or, more likely, government representations behind the scenes. The obligation to prepare and publish statements and plans offers scope for dialogue between the police and the policed. ${ }^{59}$ The former will have to set out publicly in advance the priorities they will pursue and the strategies they will deploy in pursuing them for the benefit of the latter. The minister's involvement invites the prospect of accountability in Parliament for the substance of these priorities and strategies and the Garda's performance in delivering them. This represents at least the potential for significant change from how these matters were handled during the first 85 years of the state's existence.

53 Garda Síochána Act 2005, s. 22(3).

54 Police Act 1996, s. 8 and Police (Northern Ireland) Act 1998, Part II. See Home Office, Police Reform: A police service for the twenty-first century (London: HMSO, Cm 2281, 1993). In 2002 these local annual policing plans were complemented by three-year strategy plans and annual national policing plans; Police Act 1996, ss. 6A and 36A.

55 See, Savage, Police Reform, n. 14 above; I Loader and A Mulcahy, Policing and the Condition of England (Oxford: Oxford University Press 2003); R Reiner and S Spencer, Accountable Policing: Effectiveness, empowerment and equity (London: Institute for Public Policy Research 1993).

56 See, Jones, "The accountability of policing", n. 36 above, ch. 26; Reiner, The Politics of the Police, n. 14 above, ch. 6; Walker, Policing in a Changing Constitutional Order, n. 36 above, ch. 4; E McLaughlin, The New Policing (London: Sage 2007), pp. 182-7. The House of Lords' decision in R v Chief Constable of Sussex, ex parte International Trader's Ferry Ltd [1999] 2 AC 418 illustrates the impact that the Home Secretary's national policing plans and objectives can have in shaping the operational decisions of a chief constable through the medium of a local policing plan.

57 See Police (Northern Ireland) Act 1998, ss. 14-17, 38, and 40; Police (Northern Ireland) Act 2000, ss. $24-7$.

58 The Garda Commissioner had been publishing strategy statements since 1993. The 2005 Act formalised this practice by imposing a statutory duty to publish them and by subordinating them to advance ministerial approval.

59 The Act imposes an obligation on the commissioner to make arrangements for obtaining the views of the public about matters concerning policing and the state of crime: Garda Síochána Act 2005, s. 27(1). Unfortunately, there is no express obligation to take account of these views in the plans. There is provision for the commissioner to have regard to the most recent report of each joint policing committee when preparing a plan, but it is expressed in discretionary terms: s. 22(3). 
Although the statutory obligation to promulgate strategy statements was first introduced by the 2005 Act, the Garda Commissioner had been issuing them as a matter of practice since 1993. There have been two statements spanning the years since the enactment of the 2005 Act; the first for the period 2005 to 2007 inclusive, and the second for the period 2007 to 2009.60 These statements and associated annual plans offer a useful, albeit limited, insight into how and the extent to which the concentration of control over policing at the centre is impacting on Garda priorities. A comparison between the statements and plans immediately before and after the enactment of the Garda Síochána Act 2005 is particularly useful for shedding light on the impact that the governance reforms may be having in this context.

The 2000-04 statement lists six key strategic goals: enforcing the laws relating to drugs; investigating crime; ensuring an immediate response to emergencies; providing help and support to victims of crime; contributing to improving road safety and the reduction of casualties; and maintaining state security. ${ }^{61}$ These are accompanied by a list of broad enabling strategies, which add very little of substance to the goals, and a list of Garda actions which, presumably, are meant to be performance indicators. The first five goals are uncontroversial examples of what might be expected from expressions of community preference. Indeed, it is stated that the priority listing of these five reflected the results of the public consultation exercise held by the Garda prior to the development of the strategic plan. ${ }^{62}$ Significantly, the statement does not say that state security is ranked sixth in the community's priorities. ${ }^{63}$ Instead, it asserts that state security was also mentioned as one of the things that the public wanted the Garda to do. The clear implication is that it was far from a priority among the public and that it was slipped in at six to accommodate government and institutional priorities. More ominously, it is made clear in the statement that in future the Garda will canvass regularly not just the community, but also the government, the Department of Justice, Equality and Law Reform and gardaí, on what the Garda should be doing. The results of this subtle swing away from a community to a government and institutional focus are reflected in the listing of national/international security as the number one strategic goal in all subsequent strategy statements and policing plans.

Equally disappointing from a broader community policing perspective is the failure to include specific strategic goals on matters such as: identifying and addressing the policing needs and concerns of local communities, ethnic minorities and other vulnerable groups; promoting compliance with the highest standards of human rights in the discharge of the policing function at an institutional level and in dealing with individuals and groups who are targeted for Garda attention; ensuring maximum cooperation with external supervision and accountability mechanisms; subscribing to the highest standards of transparency compatible with the delivery of an efficient and effective police service; and maximising the enjoyment of civil rights and freedoms by all individuals and groups including, in particular,

60 The reference to 2007 in the second statement is confusing as that year was already covered in the first statement. It follows that the second statement can only cover two years, even though the Act specifies a threeyear period as the norm: Garda Síochána Act 2005, s. 21(3). Interestingly, the Act empowers the minister to issue a direction for a statement to be submitted at an interval of less than three years and to cover a period less than three years: Garda Síochána Act 2005, s. 21(6). While it is not stated explicitly in the 2007-09 statement, it might be assumed that such a direction was given, perhaps in response to the revelations of the Morris Tribunal of Inquiry on Garda corruption. Significantly, the 2007-09 statement is entitled "A time for change: the Garda Síochána corporate strategy 2007-2009".

61 An Garda Síochána, Corporate Strategy 2000-2004 (Dublin: Garda Síochána 1999), p. 7.

62 Ibid. p. 13.

63 Presumably, public order and anti-social behaviour, which are surprising omissions, would have ranked much higher than state security in the community's priorities. 
those who wish to protest publicly and peacefully against the practices and policies of government and other powerful interests. ${ }^{64}$

The disproportionate emphasis on government and security concerns is reflected in a section on environmental factors and, paradoxically, a section on "putting people first". The former is focused almost exclusively on developments which will require enhanced crime control and more intrusive roles for the Garda. ${ }^{65}$ Critically, the environmental factors begin with "political factors" which are dominated by internal and external state security concerns. ${ }^{66}$ There is no reference at all to the development of civil and political rights. Even the development of audiovisual recording of the interrogation of Garda suspects is presented as a threat to effective crime control. ${ }^{67}$ State security is also given an enhanced status under the heading of "putting people first". Significantly, it is presented as "protecting you and the State". This assimilation of the policing needs of the individual and the state reflects a subtle attempt to infuse centrally directed state security policing with the traditional legitimacy associated with community-based policing. By persuading the individual to see state security policing as an integral part of community-based policing, opposition to coercive measures adopted to promote the former will be neutralised. In effect the threat of terrorism is used to encourage the individual to surrender judgment and control over policing to the wisdom of central government. This, in turn, creates the conditions in which traditional police authority and legitimacy can be hijacked by central government as an instrument to protect and promote the vested interests of select political and economic elites.

The post-2005 strategy statements do not depart fundamentally from the style and substance of the pre-2005 statement. However, there are some significant differences which reflect an increased emphasis on governmental and institutional priorities, such as state security and external cooperation over immediate community concerns and human rights values. Standard community policing concerns around crime prevention and public safety are still heavily represented, while values associated with public confidence and community engagement are given more prominence. These are overshadowed, however, by the increased prominence given to the strategic goal on national/international security which, significantly, is moved into the first position. Its contents are much more compatible with a state security and intelligence service than a community police service. One of its two primary objectives, for example, is to keep the minister "updated and briefed with timely intelligence". In the 2007-09 statement, this goal extends beyond its previous focus on terrorism to include the disruption of the interface between organised crime gangs and

64 These issues are not ignored entirely. Many of them are acknowledged in a set of guiding principles which are meant to inform how gardaí should discharge their functions. Unfortunately, they are not given the status of strategic goals, nor is it clear how they will translate from rhetoric to reality. Human rights values are acknowledged in a section on "putting people first". This includes a commitment to increase Garda training in this area and to focus on reducing complaints. Confidence in this commitment is undermined somewhat by the inexplicable failure to cite correctly the title or the year of regulations governing the treatment of persons in Garda custody. They are cited as the Treatment of Prisoners Regs 1986, instead of the Criminal Justice Act 1984 (Treatment of Persons in Garda Síochána Stations) Regs 1987.

65 The statement acknowledges that "the structures for delivering an appropriate level of accountability to local people and communities are not sufficiently developed in An Garda Síochána”. It is vague, however, on how that challenge will be addressed. This situation is not helped by the fact that the text refers to the introduction of new levels of accountability as being one of the reasons that "service to the community" is a key strategic goal for the force. The reality is that "service to the community" is not actually cited as one of the six strategic goals. It appears as one of eight "Garda Síochána Values" which are listed elsewhere in the document, but not actually explained or discussed.

66 An Garda Síochána, Corporate Strategy 2000-2004, n. 61 above, p. 8.

67 Ibid. 
subversive groups and individuals. Its expansion into territory previously occupied by the crime goal reflects an official mindset in which part of the Garda's ordinary crime control function is now seen as part of its state security function.

Another notable feature of the state security goal post-2005 is the direct role afforded to the Garda in European and international cooperation on security matters. It commits the Garda (as distinct from the government) to consult and engage "with our European and international partners regarding security issues", to participate actively "in international policing activities to facilitate intelligence gathering", to "develop further organisational capability in the management of national and international security and cooperation with our EU and international partners" and to "implement EU agreed policy/developments" in the area. Internally, it also commits itself to provide "training programmes aligned with emerging national and international security threats, making fullest use of EU programmes". Significantly, in the 2007-09 statement, this EU and international cooperation is extended beyond the traditional confines of the national and international security goal to the strategic goal on crime prevention. It is stated there that the Garda "will work in partnership with national and international enforcement agencies to identify and profile drugs trafficking networks". There is no question that the Garda must cooperate with police forces in other jurisdictions to combat the illicit drugs trade and other such transnational crimes. The wording, however, is unnecessarily broad and sets a precedent for further chunks of the Garda's domestic crime-fighting function to be reclassified as European and international cooperation and, hence, more distant from government and democratic control. ${ }^{68}$

These developments facilitate the evolution of the Garda as a constituent of an emerging European security network which is largely insulated from the traditional democratic checks and balances applicable to community policing. ${ }^{69}$ In other words, through its role in combating terrorism and organised crime, the Garda is acquiring the capacity to set its own security agenda and to operate autonomously, free from the need for prior direction or oversight from the government, let alone any other democratic checks and balances.

Further evidence of the development of the Garda as an independent centre of power in crime and security matters is provided by another interesting innovation in the 2007-09 statement. The national and international security goal includes an initiative to "develop public/private partnerships to support our national/international security operations". The notion of the Garda entering into private partnerships to pursue national or international security operations raises huge accountability and control issues. There is a very real danger that they could entail Garda policies and practices being shaped by the requirements of powerful and unaccountable private interests at home and abroad. Equally, they could entail Garda powers and resources being applied for the benefit of such private interests. Ultimately, there is a very real danger of the Garda pursing its own security agenda through such partnerships in a manner which dilutes government control, let alone control by and accountability to the community. In such a scenario, the police may develop the capacity to function beyond the reach of the democratic state.

68 S. 51 of the Garda Síochána Act 2005 makes provision for gardaí to be assigned for duties outside the state with Europol, law enforcement agencies of other states and international organisations. The 2005 Act and associated regulations will continue to apply to gardaí in the course of such duties. The real problem, of course, concerns accountability and oversight in respect of operations led by these external agencies.

69 See, generally, J Sheptycki, In Search of Transnational Policing: Towards a sociology of global policing (Aldershot: Ashgate 2002). 
The Garda's annual policing plans generally reflect the style and substance of its associated strategy statements. In many respects, the plans are a vehicle for a more detailed annual roll-out of the goals set out in the statements. Nevertheless, they frequently incorporate new matters which have been projected on to the policing agenda since the preceding statement was formulated. It is also important to note that the annual plans reflect a much more direct ministerial input. Indeed, they actually list the government's policing priorities for the year as communicated to the commissioner by the minister. The fact that these are clearly reflected in the Garda's strategic goals as set out in the plans is confirmation of central political control over policing strategy. This must be qualified, however, by an acknowledgment of a significant change in style and content between the annual plans linked to the 2000-04 strategy statement and those linked to the statements from 2005 onwards.

The annual plans up to and including 2004 reflect some commendable concessions to consensus policing values. In identifying and prioritising the strategic goals for 2003, for example, the plan pays due regard to public preferences as expressed in the Garda Public Attitude Survey of 2002. Several of the public preferences are represented in the choice and ordering of the 12 strategic goals listed for that year. Indeed, the first strategic goal of "ensuring immediate response to emergencies", reflects the top priority in the list of public preferences disclosed by the survey. Nevertheless, the political and security preferences of the government and the Garda organisation are still protected through the inclusion of several such priorities that would not have qualified on public preferences. Significantly, these include state security (goal 8) and immigration (goal 10). Conversely, key consensus policing values, such as respect for the human rights of individuals targeted for Garda action, protecting the exercise of civil liberties, responding to the needs of vulnerable minorities, and tackling Garda corruption and accountability, hardly feature at all.

One of the more attractive features of the annual policing plans up to and including 2004 is the detail offered on the content of the strategic goals. Each goal is accompanied by an explanatory text which sets out the current position with respect to the delivery of Garda services in the subject area in question, as well as an outline of the aims and objectives for the coming year. Performance indicators are also included. The net effect across all 12 strategic goals is to provide a useful insight into the police service being committed to by the Garda in key subject areas in any particular year and across the years from 2000 to 2004 inclusive. That in itself is a major contribution to transparency and, by extension, consensus policing values.

Unfortunately, there is a distinct tilt away from these values in the plans from 2005 onwards. This is most immediately obvious in the changed style. The explanatory materials that embellished and informed the strategic goals from 2000 to 2004 have disappeared from 2005 onwards. They are replaced in each goal by a clinical list of actions or targets to be taken or met over the coming year. No attempt is made to place these in the context of current Garda structures or policies. Nor is any attempt made to relate them to each other or to broader events, or to shed light on how they will be implemented. Indeed, their content and style is so sparse and functional that it is difficult for anyone outside of the relevant management specialists within the Garda to determine their significance.

Another striking change from 2005 onwards is the alignment between the goals in the annual policing plans with those in the strategy statements. The 14 goals of the 2004 policing plan, for example, are replaced by six goals in the 2005 plan. These six goals match the six goals in the strategy statement for 2005-07. This approach has been continued to the present. The net effect is that the democratic legitimacy that was claimed for the plans before 2005 has been jettisoned largely in favour of a mixture of government and Garda 
priorities. Significantly, national and international security has been promoted to goal number one, just as it is in the strategy statements from 2005. There is not even the pretence that public attitude surveys have informed the choice and ordering of priorities. On a more positive note it should be acknowledged that at least the contents of the projected actions in the plans from 2005 onwards reflect a heavier emphasis on promoting public confidence and accountability than their predecessors.

\section{Accountability to the minister}

The provisions in the 2005 Act reposing direct political powers over policing in the hands of central government are complemented by an array of provisions which render the Garda Commissioner accountable to the Minister for Justice, Equality and Law Reform. Prior to the Act, the commissioner enjoyed an extraordinary degree of statutory freedom from such accountability requirements, even to the extent of being under no obligation to submit an annual report on the management of the force or the policing of the state. ${ }^{70}$ This situation has changed utterly pursuant to the 2005 Act, which imposes a raft of accountability obligations exceeding those applicable to most, if not all, other statutory public bodies.

In addition to the standard obligation to submit an annual report and reports on any matters specified by the minister, ${ }^{71}$ the commissioner must submit a three-yearly review of the efficiency and effectiveness of the management and deployment of Garda resources ${ }^{72}$ and an annual report on the activities of the Garda's Professional Standards Unit. ${ }^{73}$ The commissioner is also under a general obligation to keep the minister and the secretary general of the department fully informed of a number of things, including: significant developments concerning the preservation of peace and public order in the state; the protection of life and property in the state; the protection of the security of the state; and significant developments that might reasonably be expected to affect adversely public confidence in the Garda Síochána. ${ }^{74}$

More striking is the fact that for the first time in the history of the state the commissioner is rendered statutorily accountable to the minister for the performance of his or her functions and those of the Garda Síochána. ${ }^{75}$ As if to emphasise the point, the Act states later that the commissioner must account fully to the government and the minister for any aspect of his or her functions. ${ }^{76}$ The accounting should be done through the secretary general of the department. It includes a duty to provide on request any document in the power or control of the Garda Síochána, including material in the form of Garda records, statements made by members of the Garda and by other persons, and reports. ${ }^{77}$ This is an alarming provision, especially as it does not expressly admit of any exceptions. In effect it places the government in a position whereby it can call on the Garda at any time for any

70 In practice, the commissioner has been submitting an annual report since the 1940s. Up until 1993, however, they were confined to crime data. Since then they have included a rather superficial treatment of aspects of the management and performance of the force generally. In the past few years they have been confined to the latter as responsibility for the publication of crime data has been transferred to the Central Statistics Office.

71 Garda Síochána Act 2005, s. 41(2) and (3).

72 Ibid. s. 23.

73 Ibid., s. 24(2). This unit was first introduced by the 2005 Act with a statutory remit to examine and review the operational, administrative and management performance of the Garda at all levels, to propose performance enhancing measures to the commissioner and to promote the highest standards of practice in operational, administrative and management matters within the Garda: s. 24(1).

74 Ibid. s. 41(1).

75 Ibid. s. 26(3).

76 Ibid. s. $40(1)$.

77 Ibid. s. 40(2). 
confidential document or record which has been compiled through the use of Garda powers and resources. While there may be situations in which it would be legitimate and proper to place such a power in the hands of government, it must be acknowledged that, in the absence of express limitations, it can also be used for more sinister reasons. In effect this power enables the government and/or the minister to use the Garda as a resource to pursue a partisan political agenda against, or at the expense of, the reputation or welfare of an individual or body.

That this is no fanciful scenario in Ireland is confirmed by the example of the minister accessing Garda intelligence on a journalist which he then supplied to another journalist who used it to publish a story linking the former journalist with suspected IRA activity. The minister followed this up by making a statement in the Dáil which openly alleged that the journalist was engaged in activities that posed a threat to national security. ${ }^{78}$ The sinister backdrop to all of this is that the journalist was the Executive Director of the Centre for Public Inquiry, an independent non-governmental body with a mission "to independently promote the highest standards of integrity, ethics and accountability across Irish public and business life, and to investigate and publicise breaches of those standards where they arise". The centre's work proved politically embarrassing for the government. As a result of the ministerial intervention, however, the centre lost its primary source of funding and had to close down.

\section{The Garda Inspectorate}

Ireland has come very late to the concept of an independent police inspectorate to oversee standards in police management, equipment, structures, processes and operations. ${ }^{79}$ It even came late in the context of the 2005 reforms, as provision for the inspectorate was only added to the Garda Bill at the committee stage in its progress through the Seanad. ${ }^{80}$ Prior to the 2005 Act, the inspectorate functions were a matter for the Department of Justice and the Garda Commissioner. In practice, they were left to the latter, as the former did not carry out regular inspections. ${ }^{81}$ The 2005 Act changed this arrangement by introducing an independent three-member ${ }^{82}$ inspectorate with a statutory remit to:

ensure that the resources available to the Garda Síochána are used so as to achieve and maintain the highest levels of efficiency and effectiveness in its

78 Dáil Debates, vol. 612, cc. 381-99.

79 An inspectorate was introduced in England and Wales in the mid-19th century: County and Borough Police Act 1856, s. 15.

80 The minister linked the inspectorate proposal to a Morris Report recommendation that the department must work in conjunction with the Garda Commissioner to address the structural defects and deficiencies outlined in the report, and that the department must be empowered by knowledge in this matter: see Report on Explosives "Finds" in Donegal, n. 9 above, para. 13.96. This is a rather tenuous peg on which to hang the introduction of the inspectorate concept.

81 There have been occasional inquiries into aspects of Garda management and operations, e.g. Report by the Committee to Recommend Certain Safeguards for Persons in Custody (Dublin: Stationery Office 1978); Commission on the Garda Síochána, Report on Conditions of Service (Dublin: Stationery Office 1979); Garda Training Committee, Report on Probationer Training (Dublin: Stationery Office 1986); Report of Committee to Inquire into Certain Aspects of Criminal Procedure (Dublin: Stationery Office 1990); Report of the Steering Group on the Efficiency and Effectiveness of the Garda Siochana (Dublin: Stationery Office 1997); Reports of the Morris Tribunal of Inquiry into Certain Gardai in the Donegal Division (Dublin: Stationery Office 2004-08).

82 Garda Síochána Act 2005, ss. 114-15. The members are appointed because of their professional experience, qualifications, training or expertise and must not be members or former members of the Garda. Currently, the Chief Inspector is Kathleen O’Toole, former police commissioner of the City of Boston. The two members are Robert Olson, former chief of police for the City of Minneapolis, and Gwen Boniface, former commissioner of the Ontario Provincial Police. 
operation and administration, as measured by reference to the best standards of comparable police services. ${ }^{83}$

Commendably the inspectorate's reports must be laid before Parliament, ${ }^{84}$ although the minister may exclude from them material which in his or her opinion would be prejudicial to the interests of national security or which might facilitate the commission of an offence or prejudice a criminal investigation or jeopardise the safety of any person. ${ }^{85}$ To date, the inspectorate has published five reports. ${ }^{86}$

When the inspectorate concept was introduced in England and Wales in the mid-19th century, it was seen as a device to enhance central government control over standards in local police forces. ${ }^{87}$ Given the national police force and its subordination to direct government control, there was not the same need for such a device in Ireland. Indeed, its introduction here could even have the effect of diluting government control by opening up an external, independent voice on police management, operations, standards and performance. In reality, however, it is meant to do the reverse. It is perceived as a device to supply the minister and the department with the objective information that they need to ensure the proper functioning of the force. ${ }^{88}$ In other words, it removes their dependence on the self-serving information supplied by the Garda Commissioner in these matters and thereby enhances their management capacity in policing matters at the expense of the commissioner. This intention is reflected in the statutory delimitation of the inspectorate's functions and in its subordination to the minister.

Significantly, the Act does not charge the inspectorate directly with the task of carrying out an annual or regular audit of Garda efficiency and effectiveness, or other regular inspections on its own initiative. ${ }^{89}$ Instead, it stipulates that the inspectorate shall carry out inspections or inquiries at the request, or with the consent, of the minister. ${ }^{90}$ The intention

83 Garda Síochána Act 2005, s. 117(1).

84 Ibid. s. 117(4). The Chief Inspector can also be called before a committee of either House in connection with the subject of a report.

85 Ibid. s. 117(5). It would appear that the Official Secrets Act 1963 applies to inspectorate reports: s. 118(5). Given the scope of prohibitions imposed by that Act, it could be used as a potent restriction on the capacity of the inspectorate to promote open and frank public discussion on weaknesses in Garda management and operations and how they might be remedied.

86 The first concerned practices and procedures for the management of barricade/siege operations: Review of Garda Siochána Practices and Procedures for Barricade Incidents (Dublin: GSI (February) 2007). The second addressed senior management structures in the Garda: Garda Siochána Senior Management Structure (Dublin: GSI (October) 2006). The third offers a broad critique of the current Garda administration and operations with a view to identifying reforms necessary to bring them into line with best international practice: Promoting Excellence and Accountability (Dublin: GSI (August) 2007). The fourth addresses the challenges of roads policing: Roads Policing Review and Recommendations (Dublin: GSI (November) 2008). The fifth addresses missing persons: Missing Persons Review and Recommendations (Dublin: GSI (March) 2009).

87 County and Borough Police Act 1856, s. 15. As a means of promoting higher standards across the country, it has been described as "one of the greatest inventions of the nineteenth century": J J Tobias, Crime and Police in England 1700-1900 (New York: St Martin's Press 1979), p. 101.

88 Dáil Debates, vol. 597, c. 962.

89 By comparison, in England, Wales and Northern Ireland, HM Inspectorate of Constabulary is statutorily charged with the duty to inspect and report annually on the efficiency and effectiveness of police forces: Police Act 1996, s. 54, and Police (Northern Ireland) Act 1998. Nevertheless, it would appear that over the past two decades the inspectorate has functioned as a vital instrument for the countrywide promotion of central government priorities, policies and standards in policing. See, Jones, "The accountability of policing", n. 36 above; Reiner, The Politics of the Police, n. 14 above; and B Golding and S Savage, "Leadership and performance management" in Newburn (ed), Handbook of Policing, n. 14 above, pp. 744-7.

90 Garda Síochána Act 2005, s. 117(2). It can also be required to provide advice to the minister with regard to best policing practice. 
is that it should examine Garda systems and performance in specific subject areas or over a specified period as requested by the minister from time to time, or as identified by itself and approved by the minister. Its programme of activities is clearly controlled by the minister. Of the five reports prepared to date, two were expressly prepared on the direction of the minister and one was suggested to the minister by the inspectorate, while the derivation of the remaining two is not clear.

While the inspectorate is generally independent in how it carries out any such examination and in the conclusions it reaches or advice that it gives, ${ }^{91}$ it is not entirely free from ministerial influence. It is statutorily prohibited from questioning or expressing an opinion on the merits or objectives of any policy of the government or of a government minister. ${ }^{92}$ In practice, this may prove a major limitation on the capacity of the inspectorate to deliver an independent and professional assessment of Garda operational and administrative efficiency. Given the degree of central government control over these aspects of the Garda organisation and operations, the inspectorate could find itself politically censored from identifying and recommending remedial measures for practices that fall below the best standards of comparable police services.

In short, the inspectorate concept has the potential to promote higher professional standards in Garda organisation and efficiency and to dilute the ministerial and Garda monopoly in these matters. The body is composed of individuals selected for their international track records in the field. It has produced a number of reports which have already enhanced standards in specific aspects of Garda organisation and practice and whose recommendations, if fully implemented, will produce further dividends. Ultimately, however, its subordination to ministerial direction is likely to stunt its full potential and might even expose it to the risk of being used as a tool to satisfy the short-term political needs of the government of the day.

\section{Counterbalancing forces}

Although this article is focused on the 2005 Act's contribution to the concentration of power in the hands of central government, it is appropriate to acknowledge that it also includes some long overdue provision for a local community input to policing in Ireland. Unlike England and Wales, Ireland has never had a tradition of local input to policing in the form of police authorities. ${ }^{93}$ Significantly, there has been a renewed interest in strengthening local input in England, Wales and Northern Ireland over the past decade, at least partly as an antidote to the stifling bureaucratic effects of increasing managerialism and direction from the centre. ${ }^{94}$ It should be no surprise therefore, that the centralising forces in the Garda Síochána Act 2005 are accompanied by some concession to local input. ${ }^{95}$ This takes the form of committees established at local authority level comprising elected representatives, gardaí and nominees from other public bodies and community

91 Garda Síochána Act 2005, s. 117(7).

92 Ibid. s. 120(2)(a).

93 In the past decade or so, initiatives have been taken on the ground, especially in parts of Dublin, to develop local police-community consultation fora primarily in response to the drugs problem: see Joint Committee on Justice, Equality, Defence and Women's Rights, Report on Community Policing (Dublin: Houses of the Oireachtas 2005).

94 See HMSO, Policing: Building Safer Communities Together (London: HMSO 2003); A New Beginning: Policing in Northern Ireland: a report of the Independent Commission on Policing in Northern Ireland (Belfast: HMSO 1999); McLaughlin, The New Policing, n. 56 above, pp. 187-94.

95 While the Act was going through the Oireachtas, the Joint Committee on Justice, Equality, Defence and Women's Rights held hearings and produced a report with recommendations on how police-community engagement could be enhanced: see Report on Community Policing, n. 93 above. 
groups. ${ }^{96}$ Their remit is to advise the local authority concerned and the Garda on how they might improve safety and quality of life and prevent crime, disorder and anti-social behaviour in their area. ${ }^{97} \mathrm{~A}$ committee can also establish neighbourhood committees to pursue these at a more local level..$^{98}$ They are expected to sit in public, and they are required to host public meetings on policing in their respective areas. ${ }^{99}$

Given the historical absence of formal provision for local democratic input to policing in the state, these provisions can be seen as a positive development in countering the excessive concentration of police power at national level. ${ }^{100}$ It would be a mistake, however, to interpret them as heralding a significant dilution of that power. They are established through the combined actions of the Garda Commissioner and the local authorities, rather than the latter alone. ${ }^{101}$ The minister controls their establishment, composition and modus operandi, including the choice of what community groups should be represented on them. The minister has exercised this power to create a situation whereby nominees from community groups are a small minority relative to gardaí, Oireachtas members and nominees from the local authorities. ${ }^{102}$ Moreover, the ministerial guidelines position the committees as a resource to assist the Garda in delivering national priorities and strategies on crime. ${ }^{103}$ Interestingly, they are still a pale version of the local reforms being pioneered in England and Wales which, in turn, represent a dilution of the initial proposals to strengthen community input at the expense of central government direction. ${ }^{104}$

It is also worth mentioning the Garda Síochána Ombudsman Commission that was introduced by the 2005 Act to replace the Garda Síochána Complaints Board. The former provides an independent check on the propriety of Garda actions and omissions. Although aimed primarily at complaints of unlawful and improper conduct on the part of individual gardaí, its existence and operations help ensure that accountability in these matters is not the exclusive preserve of the minister and the Garda Commissioner. Moreover, there is also a novel provision for the Ombudsman Commission to examine and report on a Garda practice, policy or procedure which is generating complaints. ${ }^{105}$ Once again, however, it must be acknowledged that even the independent complaints procedure is not fully insulated from the minister or from institutional Garda interests. ${ }^{106}$ As was the case with its predecessor, ${ }^{107}$ its performance is heavily dependent on the resources that the minister chooses to make available to it. Both the minister and the commissioner can use state security as a trump card to limit the efficacy of an investigation in certain circumstances. Most disappointing of all in this context is the fact that the Ombudsman Commission's

96 See Walsh, Human Rights and Policing in Ireland, n. 11 above, pp. 377-83.

97 Garda Síochána Act 2005, s. 36(2).

98 Ibid. s. 36(2)(d).

99 Ibid. s. 36(2)(c).

100 Their potential contribution is enhanced by the Garda practice of producing divisional policing plans.

101 Garda Síochána Act 2005, s. 36(1).

102 The Ionann human rights audit on the Garda Síochána had recommended a strong independent membership of these committees to complement the local authority members: Ionann Management Consultants Ltd, An Garda Siochána Human Rights Audit (June 2004), p. 26.

103 See Garda Síochána Act 2005 Joint Policing Committees Guidelines (Dublin: Department of Justice, Equality and Law Reform, September 2008).

104 HMSO, Building Communities, Beating Crime Cm 6360 (London: HMSO 2004); McLaughlin, The New Policing, n. 56 above, pp. 192-4.

105 Garda Síochána Act 2005, s. 106.

106 See Walsh, Human Rights and Policing in Ireland, n. 11 above, pp. 340-8.

107 See D P J Walsh, "Twenty years of handling police complaints in Ireland: a critical assessment of the supervisory board model” (2009) 20 Legal Studies 305. 
power to examine and report on a Garda practice, policy or procedure can be exercised only when requested by the minister. The significance of this restriction was illustrated recently when the commission sought permission to examine the Garda policing of the controversial Corrib gas pipeline project in County Mayo. Not only did the minister refuse permission, but the only explanation he gave was that it was not appropriate for him to request such an examination at that time.

\section{Conclusion}

It is undoubtedly the case that the legislative framework for the Garda Síochána, laid down at its inception in the 1920 s, dealt wholly inadequately with the relationship between the force and central government. The paucity of the Act's provisions on this vital subject facilitated the situation whereby the Garda Commissioner could find him or her self autonomous, a ministerial agent of government or somewhere in between in the direction and control of the force. In practice, all three possibilities have featured over the first 80 years of the force, but without any of them delivering credible dividends in terms of transparency and accountability. Given that context, the 2005 Act's contribution of a more comprehensive and detailed governance framework for the force is to be welcomed. Unfortunately, this may not produce significant improvements in transparency and accountability.

The architecture provided by the Act reflects an exceptional concentration of power in the hands of central government. The obfuscation of the previous arrangements has been blown away by: strengthening the government's powers of hire and fire; giving the minister powers to demand reports, to issue directives and to set strategies, priorities, standards and performance targets; and providing the minister with the machinery to assess Garda compliance with his or her own requirements and against international standards. It can be argued, of course, that this unequivocal concentration of power in the hands of the minister will provide a firmer democratic foundation for policing with associated dividends in terms of accountability, transparency and community participation. So far, however, there is no clear evidence that this is happening in practice. The Garda strategy statements and annual policing plans, for example, reflect a heavy bias in favour of government and institutional priorities. While further research is needed before any definite conclusions can be drawn, it seems that the Dáil is still not managing to play a meaningful role in scrutinising and shaping police practices. The joint policing committees are undoubtedly a welcome innovation, but they will never be able to bridge the democratic deficit at the heart of Irish policing on their own. There is immense room for further reform. ${ }^{108}$

108 See e.g. the arguments for the adoption of pluralised, multi-lateral or nodal conceptions of police governance to replace the state-centred model. Although these arguments have been presented in the context of centralising and managerial tendencies in British policing, they have equal relevance to Ireland post the 2005 Act. See L Johnston, Policing Britain: Risk, security and governance (London: Longman 2000); I Loader, "Plural policing and democratic governance" (2000) 9 Social and Legal Studies 323; C Shearing, "A nodal conception of governance: thoughts on a police commission" (2001) 11 Police and Society 259. 